\title{
PHYTOREMEDIATION OF SOILS POLLUTED WITH HEAVY METALS IN THE VICINITY OF THE ZENICA STEEL MILL IN BOSNIA AND HERZEGOVINA: POTENTIAL FOR USING NATIVE FLORA
}

\author{
SENAD MURTIĆ ${ }^{1, *}$, HAMDIJA ČIVIĆ 2 , EMINA SIJAHOVIĆ 2 , \\ ĆERIMA ZAHIROVIĆ ${ }^{1}$, EMIR ŠAHINOVIĆ ${ }^{1}$, and ADNANA PODRUG ${ }^{1}$ \\ ${ }^{1}$ Department of Plant Physiology, Faculty of Agriculture and Food Sciences University of Sarajevo, Zmaja od Bosne 8, \\ 71000 Sarajevo, Bosnia and Herzegovina \\ ${ }^{2}$ Department of Plant Nutrition, Faculty of Agriculture and Food Sciences University of Sarajevo, Zmaja od Bosne 8, \\ 71000 Sarajevo, Bosnia and Herzegovina \\ *Corresponding author: murticsenad@hotmail.com
}

\section{ABSTRACT}

This study investigates levels of soil pollution and estimates the phytoremediation potential of 7 native plants growing close to the Zenica steel mill. Plant leaves or roots and associated soil samples were collected from this site and characterized in terms of the concentrations of the heavy metals $\mathrm{Cr}, \mathrm{Cd}, \mathrm{Pb}, \mathrm{Zn}, \mathrm{Cu}$ and Ni. Heavy metal concentrations in soil and plant samples were determined using atomic absorption spectrophotometry. Bioaccumulation factors for heavy metals were also calculated. All plants studied had a low ability to remove or stabilize heavy metals in soil. This was probably associated with the poor mobility and thus poor availability of heavy metals to the plants growing in the vicinity of this steel mill.

Keywords: bioaccumulation factor; leaves; roots; soil properties

\section{Introduction}

High concentrations of heavy metals in soils can damage ecosystems and consequently human health (Fazekašová and Fazekaš 2020). Therefore, methods of preventing and for restoring soils polluted with heavy metals are needed. There are some conventional ways of restoring contaminated soils, which are based on physical and/or chemical methods, including soil washing, membrane filtration, chemical precipitation, etc. Despite being widely used, these methods have two main disadvantages: the chemicals and/or physical treatments used cause significant changes in the physicochemical and biological characteristics of soils and are very expensive (Bradl and Xenidis 2005; DalCorso et al. 2019).

Phytoremediation is a recently developed technology that reduces or stabilizes heavy metals in soils using plants (Yan et al. 2020). It is defined as plants' or root-microorganisms' ability to remove, stabilize, degrade or isolate toxic substances from the environment. Among the different phytoremediation techniques, phytoextraction and phyto stabilization are the most widely used for the rehabilitation of heavy metal polluted soils because these techniques are low cost, environmentally friendly and thus more acceptable to the public (Rai 2008; Zgorelec et al. 2020). Phytoextraction is the absorption of heavy metals by roots followed by their translocation and accumulation in the aboveground parts of plants. Plants that produce high levels of biomass grow rapidly, are easily cultivated and harvested, and most importantly, tolerate and accumulate high concentrations of heavy metals in the aboveground parts are considered to be appropriate for phytoextraction (Zhou et al. 2018). On the other hand, phytostabilization is the ability of plants to reduce the mobility of heavy metals via absorption and accumulation by roots, adsorption onto roots or by changing the solubility of heavy metals by means of root exudates. Plants native to the polluted soil that can retain large quantities of metal ions in their roots or through root exudates lower their solubility are considered to be appropriate for phytostabilization (Monaci et al. 2020). Although phytoremediation is not consistently effective, it is undoubtedly causes less damage to the environment than the use of chemicals and/or physical methods (Azubuike et al. 2016).

Unfortunately, most soils in the central and northeastern parts of Bosnia and Herzegovina are polluted with heavy metals due to industrial, mining or agriculture. This problem is particularly evident in the Zenica region where industrial activity is constantly increasing. Although the soils in this area are to a greater or lesser extent polluted with heavy metals many plants successfully grow in these soils and, therefore, these plants could be very interesting candidates as potential phytoaccumulators or phytostabilizers.

The objectives of this study were to identify the native flora growing in heavy metal polluted soils near the Zenica steel mill and evaluate the ability of some of them to remove or stabilize heavy metals in polluted soils. 


\section{Materials and Methods}

\section{Study area}

Zenica steel mill is located in the city of Zenica $\left(44^{\circ} 13^{\prime} 8^{\prime \prime} \mathrm{N}, 17^{\circ} 53^{\prime} 16^{\prime \prime} \mathrm{E}\right)$, in the Bosnia river valley, about $70 \mathrm{~km}$ northwest of Sarajevo. The climate in this area is warm and temperate. According to Köppen and Geiger, this climate is classified as $\mathrm{Cfb}$. The average annual temperature in Zenica is $11.3^{\circ} \mathrm{C}$ and rainfall is $952 \mathrm{~mm}$. The rainfall in Zenica is significant, with precipitation even during the driest month.

Three soil plots were studied in the immediate vicinity of the Zenica steel mill. All of the plots were located at a distance of about $300 \mathrm{~m}$ from the steel mill in a southeasterly direction. The plots were approximately $500 \mathrm{~m}^{2}$ in area and located within $200 \mathrm{~m}$ of each other. According to Word Reference Base for Soil Resources, the soils are classified as Leptosols (IUSS 2015). Leptosols develop on limestone, marble, dolomite and other carbonate-rich parent rocks, and as a result are neutral or slightly alkaline. Furthermore, Leptosols are well-drained soils with good aeration, but poor moisture retention; however, the capacity of these soils to promote plant growth and development is very diverse and depends primarily on the depth of the soil profile and the type of carbonate bedrock.

\section{Flora in the area studied}

Vegetation surveys were conducted in three plots measuring $5 \times 25 \mathrm{~m}$ using a quadrat sampling method to determine the composition of the flora. The high density and cover of native species of plants were the criteria for plot and quadrat selection. D.A.F.O.R scale (Dominant, Abundant, Frequent, Occasional and Rare) was used for measuring species' abundance, while plant density was determined by counting the number of individual plants of a species and dividing it by the quadrat's area. A total of 71 species of plants was identified. Also, the vegetation surveys revealed the presence of a large number of native plants belonging to the families Poaceae (12), Fabaceae (9), Asteraceae (7), Chenopodiaceae (5), Brassicaceae (4), Caryophyllaceae (4) and Rosaceae (4). In terms of density sweet clover (Melilotus officinalis (L.) Lam.) was present at the greatest density (sum of mature plant and seedling densities) (41.4 plants $/ \mathrm{m}^{2}$ ) followed by mug wort (Artemisia vulgaris L.) (24.2 plants $\left./ \mathrm{m}^{2}\right)$, chickweed (Stellaria media L.) (21.3 plants $\left./ \mathrm{m}^{2}\right)$ and blueweed (Echium vulgare L.) (18.8 plants $\left./ \mathrm{m}^{2}\right)$. Accordingly, these plants were selected for evaluating their ability to remove heavy metals from polluted soils. Ground cover value was highest for hoary mullein (Verbascum pulverulentum Vill.) and therefore this plant was also evaluated for phytoremediation purposes.

\section{Soil sampling and analysis}

Soil samples were collected in February 2020 from the three plots. The samples were taken from a depth of
0-30 $\mathrm{cm}$ using a soil sampler probe. For each plot, the samples collected from five spots (north, south, east, west and center of plot) were thoroughly mixed to obtain a composite soil sample. The collected soil samples, each weighing ca. $500 \mathrm{~g}$, were air dried, crushed and sieved through a $2 \mathrm{~mm}$ mesh. Soil $\mathrm{pH}$ was determined in $\mathrm{H}_{2} \mathrm{O}$ and $1 \mathrm{M} \mathrm{KCl}$ solution (ratio soil/solution 1:2.5) using a $\mathrm{pH}$ meter, organic matter using the potassium dichromate redox method (ISO 1998) and available forms of phosphorus and potassium using the ammonium lactate (AL) method (Egnér et al. 1960).

Heavy metals in soil samples were extracted using aqua regia with a volume ratio of $1: 3 \mathrm{HNO}_{3} / \mathrm{HCl}$ as follows: $1 \mathrm{~g}$ of air-dried, ground and sieved soil was accurately weighed in a $250 \mathrm{ml}$ round bottom flask and digested with $21 \mathrm{ml}$ of aqua regia under reflux on a hotplate for 2 hours. Resultant solutions were cooled to room temperature, filtered through Whatman No. 42 filter paper and then diluted to $100 \mathrm{ml}$ with deionized water (ISO 1995). Heavy metal concentrations in digested soil samples were determined using Atomic Absorption Spectrophotometry and a Shimadzu Atomic Absorption Spectrophotometer (AAS) model AA 7000. Calibration for each element was done using a series of standard solutions (Merck, Germany) and calibration graph with a correlation coefficient $\left(\mathrm{r}^{2}\right)>0.999$.

\section{Plant sampling and analysis}

Native herbaceous plants were collected during summer in 2020. For each species of plant, three samples were collected at random in the area where the vegetation was surveyed (quadrat). Each sample consisted of five plants that were carefully collected including as much of their roots as possible, then placed in paper bags and transported to the laboratory. Afterwards, these plants were carefully washed with distilled water, separately dried and ground, and then stored in paper bags.

Only samples of the roots of the native species of woody plants were collected during summer in 2020 . Root fragments $(<5 \mathrm{~mm}$ in diameter) from $5-15 \mathrm{~cm}$ deep were collected from five plants of each the selected species growing in the area studied. The root fragments were gently cleaned of soil particles, separately dried and ground, and then stored in bags prior to extraction.

Extraction of heavy metals from samples of plants was done as follows: $1 \mathrm{~g}$ of dried and ground plant material was placed in a $100 \mathrm{ml}$ round bottom flask and then $10 \mathrm{ml} \mathrm{HNO}_{3}$ and $4 \mathrm{ml}$ of $\mathrm{H}_{2} \mathrm{SO}_{4}$ were added. The flasks were left for few hours at room temperature and heated gently on a hot-plate until light fumes were emitted. Then, the digest was cooled down to room temperature, filtered through a Whatman No.42 filter paper into 50 $\mathrm{ml}$ flask and diluted to the mark with deionized water. Heavy metal concentrations in these solutions were also determined using Atomic Absorption Spectrophotometry. 


\section{Bioaccumulation factor}

The bioaccumulation factor (BAF) is defined as the ratio of heavy metal in the harvestable part of plants (aboveground biomass) to that in the soil in which they were growing. Accordingly, BAF was calculated using the following formula used by Kachenko and Singh (2006):

$$
B A F=\frac{C \text { shoots }}{C \text { soil }}
$$

where C shoots and C Soil are the heavy metal concentrations in the harvested aboveground plant material and soils, respectively. BAF values more than 1 indicate that the plant can tolerate or accumulate heavy metals (Petelka et al. 2019).

\section{Statistical analysis}

All measurements of plant samples were performed in triplicate and the results were presented as mean \pm standard deviation. The data were analyzed using One-Way Analysis of Variance (ANOVA) and the means compared using least significance difference (LSD) test at $5 \%$ significance level $(\mathrm{P}<0.05)$.

\section{Results}

Heavy metal concentrations and basic chemical properties of the soils studied

Concentrations of heavy metals $(\mathrm{Cr}, \mathrm{Cd}, \mathrm{Pb}, \mathrm{Zn}, \mathrm{Cu}$ and $\mathrm{Ni}$ ) in the soil in the plots are shown in Table 1.

The results indicate that concentrations of the toxic heavy metals $\mathrm{Cr}, \mathrm{Cd}$ and $\mathrm{Pb}$ in the soil in the plots located near the steel mill greatly exceed the threshold established by Bosnia and Herzegovina legislation (OG FBiH 2009). Concentrations of the potentially toxic heavy metals $\mathrm{Zn}$,
$\mathrm{Cu}$ and $\mathrm{Ni}$ also exceeded the thresholds prescribed by the same legislation, indicating that the soils close to the $\mathrm{Ze}$ nica steel mill are polluted with heavy metals. In addition to heavy metal concentrations, the soil's basic chemical parameters were recorded (Table 2).

As shown in Table 2, all the soils studied were alkaline, with high $\mathrm{CaCO}_{3}$ concentrations, moderate level of organic matter and relatively low content of available forms of phosphorus and potassium.

\section{Concentrations of heavy metals in aboveground parts of plants}

Concentrations of heavy metals $(\mathrm{Cr}, \mathrm{Cd}, \mathrm{Pb}, \mathrm{Zn}$, $\mathrm{Cu}$ and $\mathrm{Ni}$ ) in the aboveground parts of native plants that grow abundantly in the soils studied are shown in Table 3 .

For the 5 species of plants included in this study, the highest concentrations of heavy metals were recorded in the aboveground parts of Verbascum pulverulentum Vill. Concentrations of $\mathrm{Cr}, \mathrm{Cd}, \mathrm{Pb}, \mathrm{Zn}$ and $\mathrm{Ni}$ in the aboveground parts of the other native plants studied, i.e. $\mathrm{Me}$ lilotus officinalis (L.) Lam., Echium vulgare L., Stellaria media L. and Artemisia vulgaris L. were significantly lower. Moreover, concentrations of $\mathrm{Cd}, \mathrm{Pb}, \mathrm{Zn}$ and $\mathrm{Ni}$ in the above plants were lower or within the normal range of values for these elements in plants, indicating that these plants are unsuitable for phytoremediation purposes. The normal ranges of $\mathrm{Cd}, \mathrm{Pb}, \mathrm{Zn}$ and $\mathrm{Ni}$ in the leaves of plants are $0.01-2.4 \mathrm{mg} \mathrm{kg}^{-1}, 0.5-30 \mathrm{mg} \mathrm{kg}-1,20-100 \mathrm{mg} \mathrm{kg}^{-1}$ and $0.02-50 \mathrm{mg} \mathrm{kg}^{-1}$, respectively (Chaney 1989). Interestingly, the concentration of $\mathrm{Cu}$ recorded in the aboveground parts of Artemisia vulgaris L. was the highest of the plants studied. This result was unexpected since the efficiency of this plant in removing other heavy metals from the soils was very low.

Table 1 Heavy metal concentrations in the soils

\begin{tabular}{|c|c|c|c|c|c|c|}
\hline \multirow{2}{*}{ Plot } & \multicolumn{6}{|c|}{ Heavy metals (mg kg-1) } \\
\hline & $\mathrm{Cr}$ & Cd & $\mathbf{P b}$ & Zn & $\mathrm{Cu}$ & $\mathbf{N i}$ \\
\hline 1 & 117.03 & 6.39 & 835.04 & 156.82 & 92.38 & 123.11 \\
\hline 2 & 103.19 & 3.41 & 698.11 & 140.11 & 84.76 & 84.16 \\
\hline 3 & 122.44 & 5.17 & 705.43 & 153.05 & 94.23 & 120.53 \\
\hline Limit value* & 100.00 & 1.50 & 100.00 & 200.00 & 80.00 & 50.00 \\
\hline
\end{tabular}

* Limit value prescribed by legislation in Bosnia and Herzegovina.

Table 2 Basic chemical properties of the soils studied.

\begin{tabular}{|c|c|c|c|c|c|c|}
\hline \multirow{2}{*}{ Plot } & \multicolumn{6}{|c|}{ Chemical properties } \\
\hline & $\mathrm{pH}\left(\mathrm{H}_{2} \mathrm{O}\right)$ & pH (KCl) & humus (\%) & Available P (mg $100 \mathrm{~g}^{-1}$ ) & Available K (mg $100 \mathrm{~g}^{-1}$ ) & $\mathrm{CaCO}_{3}(\%)$ \\
\hline 1 & 7.80 & 7.16 & 3.10 & 3.21 & 10.30 & 8.70 \\
\hline 2 & 7.90 & 7.26 & 2.86 & 2.26 & 7.10 & 10.06 \\
\hline 3 & 7.77 & 7.22 & 2.90 & 2.03 & 9.10 & 9.61 \\
\hline
\end{tabular}


Table 3 Concentrations of heavy metals in aboveground parts of plants.

\begin{tabular}{|c|c|c|c|c|c|c|}
\hline \multirow{2}{*}{ Plant } & \multicolumn{6}{|c|}{ Heavy metals (mg kg-1) } \\
\hline & $\mathbf{C r}$ & Cd & $\mathbf{P b}$ & Zn & Cu & $\mathbf{N i}$ \\
\hline Verbascum pulverulentum Vill. & $7.45 \pm 2.08^{\mathrm{a}^{*}}$ & $0.28 \pm 0.12^{a}$ & $28.18 \pm 8.20^{a}$ & $71.98 \pm 15.06^{a}$ & $16.35 \pm 5.05^{c}$ & $4.03 \pm 2.09 a$ \\
\hline Melilotus officinalis (L.) Lam. & $0.85 \pm 0.20^{d}$ & $0.07 \pm 0.07 c$ & $1.12 \pm 0.84 c$ & $26.61 \pm 3.83^{d}$ & $13.76 \pm 6.56^{c}$ & $0.38 \pm 0.30^{d}$ \\
\hline Echium vulgare L. & $2.62 \pm 0.89^{b}$ & $0.03 \pm 0.05^{c}$ & $4.48 \pm 1.56^{b}$ & $49.34 \pm 4.02^{c}$ & $21.01 \pm 4.03^{b}$ & $3.11 \pm 1.67^{a b}$ \\
\hline Stellaria media L. & $1.52 \pm 0.88^{\mathrm{cd}}$ & $0.06 \pm 0.04 c$ & $1.86 \pm 0.82^{b c}$ & $26.47 \pm 7.41^{d}$ & $12.89 \pm 3.33^{c}$ & $0.68 \pm 0.38^{\mathrm{cd}}$ \\
\hline Artemisia vulgaris $\mathrm{L}$. & $2.03 \pm 0.37^{b c}$ & $0.14 \pm 0.12^{\mathrm{b}}$ & $3.73 \pm 1.19^{b c}$ & $63.32 \pm 8.00^{\mathrm{b}}$ & $36.04 \pm 5.12^{\mathrm{a}}$ & $1.59 \pm 1.17^{c}$ \\
\hline $\mathrm{LSD}_{0.05}$ & 0.882 & 0.069 & 3.072 & 6.663 & 3.814 & 0.988 \\
\hline
\end{tabular}

* Averages with the same letter are not significantly different $(P<0.05)$.

Table 4 Concentrations of heavy metals in the roots of plants.

\begin{tabular}{|c|c|c|c|c|c|c|}
\hline \multirow{2}{*}{ Plant } & \multicolumn{6}{|c|}{ Heavy metals (mg kg-1) } \\
\hline & $\mathbf{C r}$ & Cd & $\mathbf{P b}$ & Zn & $\mathbf{C u}$ & $\mathbf{N i}$ \\
\hline Rhus typhina L. & $5.67 \pm 3.99^{b^{*}}$ & $0.29 \pm 0.17$ & $25.01 \pm 5.03$ & $62.88 \pm 5.34$ & $16.06 \pm 4.11$ & $4.25 \pm 3.11$ \\
\hline Populus nigra L. & $23.54 \pm 4.06^{a}$ & $0.46 \pm 0.28$ & $26.13 \pm 3.39$ & $63.79 \pm 6.11$ & $14.33 \pm 5.02$ & $3.19 \pm 2.09$ \\
\hline $\mathrm{LSD}_{0.05}$ & 3.13 & - & - & - & - & - \\
\hline
\end{tabular}

* Averages with the same letter are not significantly different $(P<0.05)$.

Table 5 Bioaccumulation factor values for heavy metal transfer from soils to plants.

\begin{tabular}{|c|c|c|c|c|c|c|}
\hline \multirow{2}{*}{ Plants } & \multicolumn{6}{|c|}{ Bioaccumulation factor } \\
\hline & $\mathbf{C r}$ & Cd & $\mathbf{P b}$ & Zn & $\mathrm{Cu}$ & $\mathbf{N i}$ \\
\hline Verbascum pulverulentum Vill. & 0.064 & 0.044 & 0.034 & 0.459 & 0.177 & 0.033 \\
\hline Melilotus officinalis (L.) Lam. & 0.008 & 0.021 & 0.002 & 0.190 & 0.162 & 0.005 \\
\hline Echium vulgare $\mathrm{L}$. & 0.021 & 0.006 & 0.006 & 0.322 & 0.223 & 0.026 \\
\hline Stellaria media L. & 0.015 & 0.018 & 0.003 & 0.189 & 0.152 & 0.008 \\
\hline Artemisia vulgaris L. & 0.017 & 0.027 & 0.005 & 0.414 & 0.382 & 0.013 \\
\hline Rhus typhina L. & 0.048 & 0.045 & 0.030 & 0.401 & 0.174 & 0.035 \\
\hline Populus nigra L. & 0.201 & 0.072 & 0.031 & 0.407 & 0.155 & 0.026 \\
\hline
\end{tabular}

\section{Concentrations of heavy metals in the roots of plants}

Concentrations of heavy metals $(\mathrm{Cr}, \mathrm{Cd}, \mathrm{Pb}, \mathrm{Zn}, \mathrm{Cu}$ and $\mathrm{Ni}$ ) in the roots of the selected native woody plants growing in the soils studied soils shown in Table 4.

There are no significant differences in the concentrations of heavy metals in the roots of the woody plants studied except for $\mathrm{Cr}$, which was significantly higher in roots of black poplar (Populus nigra L.) than staghorn sumac (Rhus typhina L.).

\section{Bioaccumulation factor values for heavy metal transfer from soils to plants}

Bioaccumulation factor (BAF) values for $\mathrm{Cr}, \mathrm{Cd}, \mathrm{Pb}$, $\mathrm{Zn}, \mathrm{Cu}$ and $\mathrm{Ni}$ for the plants studied area are shown in Table 5.

A total of seven species of plants consisting of five herbaceous plants and two trees had BAF values below 1 for each of the heavy metals, indicating that none of the plants is suitable for phytoremediation purposes.

\section{Discussion}

The present study found that the levels of $\mathrm{Pb}, \mathrm{Cr}, \mathrm{Cd}$, $\mathrm{Cu}$ and $\mathrm{Ni}$ in the soils studied greatly exceeded the maximum allowable concentrations for agricultural soils. This is not surprising as all the soil studied came from plots situated close to the steel mill. Previous studies carried out in this area also indicate the soils there are polluted with toxic heavy metals (Bikić and Omerović 2012; Prcanović et al. 2012). Therefore, in order to reduce soil pollution caused by heavy metals in the vicinity of steel mills, more attention should be paid to the remediation of contaminated soils.

The present study focuses on the remediation of soils polluted with heavy metals using phytoaccumulation and Phyto stabilization. In order to achieve this goal, the present study evaluated the phytoaccumulation potential of five native herbaceous plants: Verbascum pulverulentum Vill, Melilotus officinalis (L.) Lam., Echium vulgare L., 
Stellaria media L., Artemisia vulgaris L. and the phytostabilization potential of two native woody plants: Rhus typhina L. and Populus nigra L. These plants grow in soils polluted with heavy metals without suffering any toxic effects, which is why they were included in this study. Several studies report that some of the above-mentioned plants can accumulate large amounts of heavy metals (Chandra et al. 2016; Gajić et al. 2018; Jakovljević et al. 2019), however, little is known about their ability to accumulate heavy metals when growing around the Zenica steel mill.

The BAF analyses revealed that these plants are efficient in accumulating $\mathrm{Zn}$ and $\mathrm{Cu}$. BAF values for $\mathrm{Zn}$, $\mathrm{Cu}, \mathrm{Cr}, \mathrm{Cd}, \mathrm{Ni}$ and $\mathrm{Pb}$, however, ranged from 0.189 to $0.459,0.152$ to $0.382,0.015$ to $0.201,0.006$ to $0.044,0.005$ to 0.035 and 0.002 to 0.034 , respectively. This pattern of heavy metal accumulation in plants characterized by high bioaccumulation rates for $\mathrm{Cu}$ and $\mathrm{Zn}$ and low values for $\mathrm{Cr}, \mathrm{Cd}, \mathrm{Ni}$ and $\mathrm{Pb}$ is not surprising considering the importance of these elements for plant growth and development, as $\mathrm{Cu}$ and $\mathrm{Zn}$ are essential elements for plants and their presence in acceptable concentrations is crucial for maintaining their metabolic processes. Thus, plants have evolved mechanisms for the uptake and transport of both $\mathrm{Zn}$ and $\mathrm{Cu}$ (Bahamonde et al. 2019). On the other hand, $\mathrm{Cr}, \mathrm{Cd}, \mathrm{Ni}$ and $\mathrm{Pb}$ are highly toxic to plants even at very low concentrations, and therefore, many plants have developed different mechanisms for reducing their uptake and/or translocation. These mechanisms are mainly based on heavy metal compartmentalization in root cells, or biosynthesis of phytochelatins that bind with heavy metals and prevent their transport from roots to aboveground parts of plants (Anjum et al. 2015).

Interestingly, the lowest bioaccumulation rates recorded in this study were for $\mathrm{Pb}$, suggesting that plants under $\mathrm{Pb}$ stress have mechanisms for reducing $\mathrm{Pb}$ uptake and translocation. Huang et al. (2017) report that cell walls of root cells restrict $\mathrm{Pb}$ uptake and thus act as an important protective barrier. That is, the $\mathrm{Pb}$ fixation by pectates in the walls of root cells prevents the entry of $\mathrm{Pb}$ into the internal tissues and its translocation within the plant.

The majority of studies report that ion homeostasis in plasmatic compartments is of great importance for the acclimation of plants to heavy metals stress conditions (Wiszniewska et al. 2019; Anwar and Kim 2020). Low toxic heavy metal ion activities in cytosol, nucleoplasm, mitochondria and other plasmatic compartments ensure regular functioning of metabolic processes and may be achieved mainly by vacuolar compartmentalization. Thus, in order to avoid heavy metal toxicity, plants accumulate toxic heavy metals in vacuoles, which indicate that vacuoles have a detoxification function. That is, non-hyperaccumulator plants largely accumulate toxic heavy metals in root vacuoles, while hyperaccumulator plants usually accumulate them in vacuoles in leaf cells following efficient long-distance transport. The different strategies of non-hyperaccumulator and accumulator plants are associated with organ-specific differences in cell compartments, particularly in transition metal transporters (Sharma et al. 2016).

In view of the fact that all the herbaceous plants growing in the polluted soils in the vicinity of Zenica steel mill studied had relatively low heavy metal concentrations in leaves and low BAF values for toxic heavy metals, it is concluded that the above-mentioned plants cannot be regarded as hyperaccumulator plants. However, regardless of these findings, interestingly the concentrations of the hazardous heavy metals $\mathrm{Cr}, \mathrm{Cd}$ and $\mathrm{Pb}$ were 5 to 15 -fold higher in the leaves of Verbascum pulverulentum Vill., than in leaves of the other plants studied. These findings undoubtedly indicate that the ability of these plants to accumulate heavy metals depends, among other factors, on the plants' genetic background (Koźmińska et al. 2018).

Regarding BAF values, many scientists argue that a BAF $>1$ does not necessarily indicate a plant is a hyperaccumulator (e.g., Robinson et al. 1998; Zhao et al. 2003). A value $>1$ is unlikely to be recorded for plants growing on soils contaminated with heavy metals if the soil chemical and physical properties negatively affect the mobility of heavy metals and thus their availability to plants. That is, BAF is an effective way of assessing the mobility/availability of heavy metals in soils (Bempah and Ewusi 2016).

The results of this study also indicate that specific chemical properties of soils i.e. a high $\mathrm{pH}$ value and $\mathrm{CaCO}_{3}$ content probably result in a significant reduction in the bioavailability of heavy metals, resulting in low BAF values and low accumulation of heavy metals in leaves. Many studies report that with increasing $\mathrm{pH}$, organic matter and $\mathrm{CaCO}_{3}$ content the mobility of most heavy metals in soils decreases due to their increased adsorption (Hamid et al. 2018; Palansooriya et al. 2020). In other words, in alkaline soils with high organic matter and $\mathrm{CaCO}_{3}$ content, heavy metal ions tend to form insoluble hydroxides, carbonates and organic complexes and are unavailable to plants (Rieuwerts et al. 1998).

In this study, the Phyto stabilization potential of two native woody plants: Rhus typhina L. and Populus nigra L. was also evaluated. Unfortunately, the roots of both these plants have low ability to take up and accumulate heavy metals, which indicates that their potential for Phyto stabilization is low. This is probably due to the chemical properties of the soils, which is in accordance with the correlation between soil properties and he availability of heavy metals as described above.

Overall, the results of this study confirmed that the soils in the vicinity of the Zenica steel mill are contaminated with the hazardous heavy metals $\mathrm{Cr}, \mathrm{Cd}, \mathrm{Ni}$ and $\mathrm{Pb}$. Furthermore, all the plants studied had a low ability to remove or stabilize heavy metals in the soil. This was probably due to the chemical properties of soils restricting the mobility of the heavy metals and thus their availability to plants. Thus, it is concluded that heavy metal uptake by plants is a complex soil-plant process, influ- 
enced primarily by plant genetic background and soil physicochemical properties.

\section{Acknowledgements}

We are grateful for the financial support for this research from the Ministry of Education, Science and Youth of Sarajevo Canton.

\section{REFERENCES}

Anjum NA, Hasanuzzaman M, Hossain MA, Thangavel P, Roychoudhury A, Gill SS, Rodrigo MA, Adam V, Fujita M, Kizek R, Duarte AC, Pereira E, Ahmad I (2015) Jacks of metal/metalloid chelation trade in plants-an overview. Front Plant Sci 6: 192. doi: $10.3389 /$ fpls.2015.00192.

Anwar A, Kim J-K (2020) Transgenic Breeding Approaches for Improving Abiotic Stress Tolerance: Recent Progress and Future Perspectives. Int J Mol Sci 21: 2695. doi: 10.3390/ijms21082695.

Azubuike CC, Chikere CB, Okpokwasili GC (2016) Bioremediation techniques - classification based on site of application: principles, advantages, limitations and prospects. World J Microbiol Biotechnol 32: 180. doi: 10.1007/s11274-016-2137-x.

Bahamonde HA, Fernández V, Gyenge J, Mattenet F, Peri PL (2019) Essential Nutrient and Trace Element Foliar Resorption of Two Co-Existing Nothofagus Species Grown Under Different Environmental Conditions in Southern Patagonia. Front Plant Sci 10: 1542. doi: 10.3389/fpls.2019.01542.

Bempah CK, Ewusi A (2016) Heavy metals contamination and human health risk assessment around Obuasi gold mine in Ghana. Environ Monit Assess 188: 261. doi: 10.1007/s10661-016 -5241-3.

Bikić F, Omerović L (2012) Analysis of soil sites Tetovo on heavy metals and assessment of pollution. 2nd International Symposium on Environmental Management and Material Flow Management EMFM 2012; 2012 June 7-9; Zenica, Bosnia and Herzegovina.

Bradl H, Xenidis A (2005) Remediation techniques. In: Bradl HM (ed) Heavy Metals in the Environment: Origin, Interaction and Remediation. Cambridge (MA), Elsevier, pp 165-261.

Chandra R, Cho W, Kang H (2016) Phytoextraction potential of four poplar hybrids under greenhouse conditions. Forest Sci Technol 12: 199-206. doi: 10.1080/21580103.2016.1180325.

Chaney RL (1989) Toxic element accumulation in soils and crops: Protecting soil fertility and agricultural foodchains. In: Bar-Yosef B, Barrow NJ, Goldshmid J (eds) Inorganic contaminants in the Vadose Zone. Berlin, Springer, pp 140-158.

DalCorso G, Fasani E, Manara A, Visioli G, Furini A (2019) Heavy Metal Pollutions: State of the Art and Innovation in Phytoremediation. Int J Mol Sci 20: 3412. doi: 10.3390/ijms20143412.

Egnér H, Riehm H, Domingo WR (1960) Untersuchungen über die chemische Boden analyse als Grundlage für die Beurteilung de Nährstoffzustandes der Böden. II. Chemische Extraktions methoden zur Phosphor- und Kaliumbestimmung. Kungl Lantbrukshögsk Ann 26: 199-215.

Fazekašová D, Fazekaš J (2020) Soil Quality and Heavy Metal Pollution Assessment of Iron Ore Mines in Nizna Slana (Slovakia). Sustainability 12: 1-15. doi: 10.3390/su12062549.

Gajić G, Djurdjević L, Kostić O, Jarić S, Mitrović M, Pavlović P (2018) Ecological Potential of Plants for Phytoremediation and
Ecorestoration of Fly Ash Deposits and Mine Wastes. Front Environ Sci 6: 124. doi: 10.3389/fenvs.2018.00124.

Hamid Y, Tang L, Wang X, Hussain B, Yaseen M, Aziz MZ, Yang X (2018) Immobilization of cadmium and lead in contaminated paddy field using inorganic and organic additives. Sci Rep 8: 17839. doi: 10.1038/s41598-018-35881-8.

Huang L, Zhang H, Song Y, Yang Y, Chen H, Tang M (2017) Subcellular Compartmentalization and Chemical Forms of Lead Participate in Lead Tolerance of Robinia pseudoacacia L. with Funneliformis mosseae. Front Plant Sci 8: 517. doi: 10.3389/fpls .2017.00517.

ISO (1995) International Standard ISO 11466: Soil quality - Extraction of trace elements soluble in aqua regia. International Organization for Standardization, Geneva, Switzerland.

ISO (1998) International Standard ISO 14235: Soil quality - Determination of organic carbon in soil by sulfochromic oxidation. International Organization for Standardization, Geneva, Switzerland.

IUSS International Union of Soil Sciences (2015) World Reference Base for Soil Resources: International soil classification system for naming soils and creating legends for soil maps. Word Soils Resources Reports, Rome, Italy.

Jakovljević K, Đurović S, Antušević M, Mihailović N, Buzurović U, Tomović G (2019) Heavy metal tolerance of Pontechium maculatum (Boraginaceae) from several ultramafic localities in Serbia. Bot Serb 43: 73-83. doi: 10.2298/BOTSERB1901073J.

Kachenko AG, Singh B (2006) Heavy Metals Contamination in vegetables grown in urban and metal smelter contaminated sites in Australia. Water Air Soil Pollut 169: 101-123. doi: 10 .1007/s11270-006-2027-1.

Koźmińska A, Wiszniewska A, Hanus-Fajerska E, Muszyńska E (2018) Recent strategies of increasing metal tolerance and phytoremediation potential using genetic transformation of plants. Plant Biotechnol Rep 12: 1-14. doi: 10.1007/s11816-017-0467-2.

Monaci F, Trigueros D, Mingorance MD, Rossini-Oliva S (2020) Phytostabilization potential of Erica australis L. and Nerium oleander L.: a comparative study in the Riotinto mining area (SW Spain). Environ Geochem Health 42: 2345-2360. doi: 10 .1007/s10653-019-00391-7.

OG FBiH, Official Gazette of FBiH (2009) Rulebook on determination of allowable quantities of harmful and hazardous substances in soils of Federation of Bosnia and Herzegovina and methods for their testing No 72/09. Sarajevo, Bosnia and Herzegovina.

Palansooriyaa KN, Shaheen SM, Chen SS, Tsang DCV, Hashimoto Y, Hou D, Bolan NS, Rinklebe J, Ok YS (2020) Soil amendments for immobilization of potentially toxic elements in contaminated soils: A critical review. Environ Int 134: 105046. doi 10.1016/j.envint.2019.105046

Petelka J, Abraham J, Bockreis A, Deikumah JP, Zerbe S (2019) Soil Heavy Metal(loid) Pollution and Phytoremediation Potential of Native Plants on a Former Gold Mine in Ghana. Water Air Soil Pollut 230: 267. doi: 10.1007/s11270-019-4317-4.

Prcanović H, Duraković M, Beganović S (2012) Concentration of lead, cadmium, and iron in sediment dust and total suspended particles before and after initialisation of integral production in iron and steel work plant Zenica. Arh Hig Rada Toksikol 63: 181-188. doi: 10.2478/10004-1254-63-2012-2191.

Rai PK (2008) Heavy Metal Pollution in Aquatic Ecosystems and its Phytoremediation using Wetland Plants: An ecosustainable approach. Int J Phytoremediat 10: 133-160. doi: 10.1080 /15226510801913918.

Rieuwerts JS, Thornton I, Farago ME, Ashmore MR (1998) Factors influencing metal bioavailability in soils: preliminary in- 
vestigations for the development of a critical loads approach for metals. Chem Spec Bioavailab 10: 61-75. doi: 10.3184 /095422998782775835.

Robinson BH, Leblanc M, Petit D, Brooks RR, Kirkman JH, Gregg PEH (1998) The potential of Thlaspi caerulescens for phytoremediation of contaminated soils. Plant Soil 203: 47-56. doi: 10 .1023/A:1004328816645.

Sharma SS, Dietz KJ, Mimura T (2016) Vacuolar compartmentalization as indispensable component of heavy metal detoxification in plants. Plant Cell Environ 39: 1112-1126. doi: 10.1111 /pce.12706.

Wiszniewska A, Muszyńska E, Kołton A, Kamińska I, Hanus-Fajerska E (2019) In vitro acclimation to prolonged metallic stress is associated with modulation of antioxidant responses in a woody shrub Daphne jasminea. Plant Cell Tiss Organ Cult 139: 339-357. doi: 10.1007/s11240-019-01688-2.
Yan A, Wang Y, Tan SN, Mohd Yusof ML, Ghosh S, Chen Z (2020) Phytoremediation: A Promising Approach for Revegetation of Heavy Metal-Polluted Land. Front Plant Sci 11:359. doi: 10.3389 /fpls.2020.00359.

Zgorelec Ž, Bilandžija N, Knez K, Galić M, Žužul S (2020) Cadmium and Mercury phytostabilization from soil using Miscanthus $\times$ giganteus. Sci Rep 10: 6685. doi: 10.1038/s41598-020-63488-5.

Zhao FJ, Lombi E, McGrath SP (2003) Assessing the potential for zinc and cadmium phytoremediation with the hyperaccumulator Thlaspi caerulescens. Plant Soil 249: 37-43. doi: 10.1023 /A:1022530217289.

Zhou J, Zhou T, Li Z, Wu L, Luo Y, Christie P (2018) Differences in phytoextraction by the cadmium and zinc hyperaccumulator Sedum plumbizincicola in greenhouse, polytunnel and field conditions. Int J Phytoremediat 20: 1400-1407. doi: 10.1080 /15226514.2018.1488808. 